\title{
Penerapan Model Number Head Together (NHT) dalam Meningkatkan Hasil Belajar Matematika pada Siswa Sekolah Dasar
}

\author{
Linggar Setiyowati ${ }^{1}$, Ety Nur Inah ${ }^{2}$ \\ ${ }^{1}$ Institut Agama Islam Negeri Kendari \\ ${ }^{2}$ Institut Agama Islam Negeri Kendari, Indonesia. E-mail: ety_nurinah@yahoo.com
}

\begin{abstract}
Articel info
Artikel history:

Received: 4 April 2020

Revised: 18 April 2019

Accepted: 18 April 2020

Abstract

This research aims to investigate the implementation of Numbered Head Together (NHT) to improve student's mathematic learning outcome at four grade of elementary school 18 Baruga. This study is an action class research. The data were collected throught observation, documentation, and test. The subject of the study was four-grade students of elementary school 18 Baruga with 26 in number. Based on the study, the use of teaching model of Numbred Head Together can improve student's mathematic learning outcome on the subject of the greatest and smallest common devisor with $80 \%$ in both average and completeness score. Before the treatment, the completeness rate of the learning activities was $23.07 \%$ with 50.76 average score, then with average score 63.46 it rose to $46.15 \%$ in the first cycle. In the last meeting both the score rose significantly with $88,46 \%$ for the completeness rate and 85.38 for average score.
\end{abstract}

Keywords: Numbered Head Together, the greatest and the smallest common deviser, Student's learning outcome
Informasi Artikel

Riwayat Artikel:

Diterima: 4 April 2020

Direvisi: 18 April 2020

Accepted: 18 April 2020
Abstrak

Penelitian ini bertujuan untuk mengetahui penerapan model pembelajaran Number Head Together (NHT) dalam meningkatkan hasil belajar matematika pada siswa kelas IVa SDN 18 Baruga. Penelitian ini adalah penelitian tindakan kelas (PTK). Instrumen yang digunakan yaitu lembar observasi, dokumentasi, dan tes. Subjek penelitian siswa kelas IVa SDN 18 Baruga dengan jumlah siswa 26 orang yang terdiri dari 13 orang perempuan dan 13 orang laki-laki. Berdasarkan hasil penelitian, penggunaan model Number Head Together (NHT) pada siswa kelas IVa SDN 18 Baruga dengan materi Faktor Persekutuan Terbesar (FPB) dan Kelipatan Persekutuan Terkecil (KPK) dapat meningkatkan hasil belajar siswa dengan peningkatan nilai rata-rata dan presentase ketuntasan belajar mencapai $80 \%$. Presentase ketuntasan belajar matematika siswa kelas IVa sebelum tindakan mencapai 23,07\% dengan nilai rata-rata 50,76. Setelah dilakukannya tindakan siklus I menunjukkan adanya peningkatan hasil belajar, adapun presentase hasil belajar siswa siklus I yaitu 46,15\% dengan nilai rata-rata 63,46. Namun belum mencapai indikator keberhasilan yaitu $80 \%$ siswa memperoleh nilai $\geq 70$, sehingga dilanjutkan pada siklus II. Pada siklus II hasil belajar siswa meningkat dengan presentase mencapai $88,46 \%$ dengan nilai rata-rata 85,38 bahkan melebihi indikator yang telah 


\section{PENDAHULUAN}

Pendidikan merupakan suatu kebutuhan yang harus dipenuhi dalam kehidupan bermasyarakat, berbangsa dan bernegara. Maju mundurnya suatu bangsa ditentukan oleh kualitas pendidikan bangsa itu sendiri. Kompleksnya masalah kehidupan menuntut sumber daya manusia handal dan mampu berkompetensi. Selain itu pendidikan merupakan wadah yang dapat dipandang sebagai pembentuk sumber daya manusia yang bermutu tinggi. Berhasil atau tidaknya suatu proses pendidikan sangat dipengaruhi oleh pembelajaran yang berlangsung. pembelajaran adalah interaksi pendidik dan peserta didik dalam mempelajari suatu materi pelajaran yang telah tersusun dalam suatu kurikulum. Pembelajaran adalah suatu proses yang rumit karena tidak sekedar menyerap informasi dari guru tetapi melibatkan berbagai kegiatan dan tindakan yang harus dilakukan untuk mendapatkan hasil belajar yang lebih baik. (Sri Hariyanti dan Naim Musyafik, 2013).

Proses pembelajaran terdiri atas sejumlah komponen atau unsur yang saling berkaitan dan saling berinteraksi satu sama lain. Proses pembelajaran merupakan kegiatan interaksi antara lain yaitu guru dan peserta didik pada saat proses pembelajaran berlangsung. Kegagalan guru dalam menyampaikan suatu pokok bahasan disebabkan saat proses pembelajaran guru kurang membangkitkan perhatian dan aktivitas peserta didik dalam mengikuti pelajaran. Sedangkan keberhasilan guru dalam mengajar dipengaruhi oleh kemampuan dan ketepatan guru dalam menguasai materi, memilih dan menggunakan metode pembelajaran. Oleh karena itu suasana pembelajaran yang dikembangkan oleh guru memegang peranan penting untuk mencapai tujuan yang diinginkan sehingga berpengaruh terhadap keberhasilan dan kegagalan belajar siswa, (Irhas, 2014). Disinilah peran guru untuk memilih model pembelajaran yang tepat dalam menyelenggarakan pembelajaran matematika, terutama pembelajaran yang dapat menghapus bayangan buruk terhadap bidang studi matematika. Setiap guru mengharapkan agar setiap ilmu pengetahuan yang di ajarkan dapat di mengerti, sehingga keberhasilan guru saat mengajar tercapai dengan baik. Hal ini dapat di laksanakan dengan memilih salah satu model pembelajaran yang tepat dalam rangka mengoptimalkan hasil belajar siswa, (Titin Hartanti, 2013).

Kenyataan di sekolah banyak guru yang kurang mempunyai kemampuan dan kreatifitas dalam memilih, membuat dan menggunakan media serta motode pembelajaran saat proses pembelajaran. Banyak guru yang masih menggunakan metode ceramah dalam menyampaikan materi dikelas dan penggunaan media pembelajaran yang belum optimal, sehingga siswa kurang bergairah dalam mengikuti pembelajaran, tidak terlihat antusias, bersikap acuh tak acuh, dan siswa belum aktif dalam proses pembelajaran. Saat kegiatan pembelajaran berlangsung, guru lebih mendominasi kelas sehingga siswa cenderung pasif dan aktivitas yang dilakukan hanya mendengarkan dan mencatat penjelasan guru. Akibatnya siswa menjadi takut dan malu bertanya jika mengalami kesulitan dalam memahami materi yang diberikan (Observasi Guru, 17 Juli 2018).

Berdasarkan hasil wawancara peneliti yang dilakukan pada tanggal 17 Juli 2018, terungkap bahwa hasil belajar siswa pada mata pelajaran matematika masih rendah dengan rata-rata hasil belajar siswa mendapat nilai 51 (tes awal), dilihat dari hasil belajar kognitif. Hal ini dipengaruhi oleh perhatian siswa dalam disksusi maupun belajar karena pembelajaran yang masih berpusat pada guru serta penggunaan model dan media yang tidak optimal, sehingga masih didapati siswa yang bermain pada saat pembelajaran. Bila dilihat dari hasil ulangan matematika ada sebanyak 6 siswa atau sekitar 23\% yang telah mencapai Kriteria Ketuntasan Minimal (KKM) dengan nilai 70, sedangkan sisanya ada sebanyak $77 \%$ atau sekitar 20 siswa yang tidak mencapai KKM dan hanya mendapat nilai 65 ke bawah. Selain itu, siswa yang kurang aktif dalam pembelajaran yang hanya menerima pengetahuan yang datang dari guru tanpa berusaha untuk menggali informasi dari sumber belajar yang lain. (Wawancara Guru, 17 Juli 2018).

Berdasarkan hal-hal yang telah dijelaskan di atas, peneliti berpendapat perlu adanya perbaikan proses pembelajaran pada siswa kelas IVa SDN 18 Baruga melalui model pembelajaran Number Head Together (NHT). Hal ini dilakukan dengan tujuan agar hasil belajar siswa meningkat serta siswa dapat 
ikut berperan aktif selama proses pembelajaran berlangsung seperti diskusi dan tanya jawab sehingga proses pembelajaran di kelas lebih menarik, menyenangkan dan siswa dapat mengembangkan potensinya secara maksimal. Melalui Number Head Together (NHT) siswa diharapkan akan terlibat dalam proses pembelajaran yang dilaksanakan oleh guru, seperti kegiatan Numbered yaitu kegiatan pembentukkan kelompok secara heterogen yang dilakukan oleh guru, Questioning yaitu pemberian bahan diskusi atau pertanyaan yang nantinya akan didiskusikan oleh tiap-tiap kelompok, Head Together yaitu mendiskusikan masalah dengan cara bekerja sama untuk menemukan jawaban dari masalah atau pertanyaan yang diberikan, dan Answering yaitu mempresentasikan atau menjawab masalah-masalah yang telah didiskusikan berdasarkan nomor kepala yang diberikan. Hasil penelitian Rika Firma Yeni (2016) mengungkapkan salah satu alternatif yang digunakan untuk mengatasi permasalahan rendahnya hasil belajar matematika siswa adalah dengan menggunakan metode Numbered Head Together (NHT). Metode ini merupakan salah satu bentuk pembelajaran kooperatif yang menuntut siswa untuk bekerja sama dalam suatu kelompok kecil untuk menuntaskan materi pelajarannya. Hasil penelitian La Anse dan Muhammad Ilham (2018) dengan judul The Implementation of Cooperative Learning (Numbered Head Together) to Boost Students' Learning Outcome in Social Studies Subject menunjukkan bahwa terdapat peningkatan hasil belajar siswa di SD melalui pembelajaran NHT setelah dilaksanakan dua siklus pembelajaran.

\section{METODE}

Penelitian ini merupakan jenis penelitian tindakan kelas (PTK). Mutia Agisni, dkk mengatakan bahwa penelitian tindakan kelas bertujuan untuk memahami kondisi yang terjadi pada saat pembelajaran berlangsung dan untuk mengatasi permasalahan-permasalahan yang ada dalam pembelajaran sehingga adanya tindakan untuk memecahkan setiap permasalahan-permasalahan untuk mengarahkan kepada hasil yang lebih baik, (Mutia Agisni, Dkk 2016). Jadi penelitian tindakan kelas adalah penelitian yang sengaja dilakukan guru dalam sebuah kelas atau dalam ruang lingkup pendidikan untuk meningkatkan kualitas pendidikan melalui refleksi diri dengan tujuan untuk memperbaiki kinerja guru. PTK ini dilaksanakan dengan menerapkan model pembelajaran Number Head Together (NHT) untuk meningkatkan hasil belajar Matematika siswa kelas IVa SDN 18 Baruga Kecamatan Baruga Kota Kendari. Prosedur penelitian ini adalah penelitian tindakan kelas yang pelaksanaanya menggunakan pola siklus, dimana setiap siklus membutuhkan dua atau tiga kali pertemuan, tiap siklus dilaksanakan sesuai dengan perubahan-perubahan yang dicapai pada faktor-faktor yang diselidiki dan tingkat penyelesaian penelitian tergantung pada sejauh mana tingkat pencapaian keberhasilan pembelajaran yang disesuaikan dengan standar penilaian. Adapun teknik yang digunakan untuk mengumpulkan data penelitian yaitu observasi, wawancara, dokumentasi dan tes. Penelitian tindakan kelas ini dilaksanakan dan direncanakan dalam dua siklus. Setiap siklus terdiri dari 4 tahap yang meliputi tahap perencanaan, pelaksanaan, observasi dan refleksi dan tiap siklus terdiri dari dua pertemuan, dilaksanakan sesuai dengan perubahan yang ingin dicapai pada faktor yang diselidiki.

\section{HASIL PENELITIAN \\ Pra Siklus}

Penelitian ini di awali dengan melakukan observasi awal di SDN 18 Baruga untuk mengambil data awal sebelum dilakukan penelitian, peneliti juga bertemu dengan Kepala Sekolah untuk menjelaskan maksud kedatangan peneliti di SDN 18 Baruga. Kemudian peneliti melakukan survey dari beberapa kelas tinggi diantaranya kelas 4, 5 dan 6 untuk melihat masalah-masalah yang perlu dilakukan penelitian. Peneliti juga melakukan wawancara singkat dengan beberapa wali kelas dan kemudian peneliti tertarik pada kelas IVa dengan Wali Kelas yaitu Bapak Nurkholis, S.Pd.I. Hasil wawancara tersebut yakni peneliti menemukan ada beberapa masalah di kelas IVa yang perlu diperbaiki yaitu pada pelajaran matematika dimana hasil belajar pada mata pelajaran matematika masih rendah disebabkan para siswa masih sulit memahami materi yang diajarkan oleh guru dan proses pembelajaran masih menonton dikarenakan guru masih menggunakan metode konvensional (Hasil Obsevasi dan Wawancara Wali Kelas IVa Bapak Nurkholis, S.Pd,I).

Berdasarkan analisis hasil belajar diatas, perolehan nilai tes awal yang paling tertinggi adalah nilai 70 dan nilai paling rendah adalah 40 dengan nilai rata-rata hasil belajar siswa sekitar 51 
sementara ketuntasan yang diperoleh hanya $23 \%$ dan yang tidak tercapai ketuntasan $77 \%$ berarti jumlah siswa yang tidak mencapai untuk nilai ketuntasan klasikal adalah 20 siswa atau sekitar $77 \%$ dan yang mengalami ketuntasan klasikal adalah 6 siswa atau sekitar 23\%. Hal ini terjadi karena siswa pada umumnya lebih banyak diam dan hanya mendengarkan penjelasan guru, siswa juga masih banyak melakukan kesalahan dalam menyelesaikan soal-soal yang diberikan serta disebabkan pemahaman siswa terhadap konsep-konsep dasar materi pembelajaran masih sangat kurang. Seperti yang dijelaskan dalam penelitian mereka bahwa dalam pembelajaran matematika sebagian besar siswa masih malu untuk bertanya dan mengemukakan pendapatnya, kurangnya rasa tanggung jawab siswa terhadap tugas-tugas yang diberikan guru, serta sebagian besar siswa masih kurang aktif sehingga dalam pembelajaran siswa hanya bersikap pasif, (Aniza, Muh. Hasbi dan Baharuddin, 2017). Sikap inilah yang mengakibatkan atau menimbulkan kesulitan-kesulitan bagi siswa dalam mengerjakan dan memahami materi yang diajarkan guru, akibatnya siswa tidak memahami materi pembelajaran sehingga hasil belajar siswa menjadi rendah.

Menyikapi hasil dari tes awal yang telah dilaksanakan, maka perlu adanya perbaikan yaitu dengan memberikan peran yang lebih banyak pada siswa dalam proses pembelajaran agar siswa lebih aktif dalam proses pembelajaran, hal ini dapat dilakukan dengan strategi dan model pembelajaran yang tepat serta bervariasi agar nantinya hasil belajar siswa semakin baik dan meningkat. Peneliti dalam hal ini akan melakukan tindakan pada siswa untuk meningkatkan hasil belajar siswa dengan menggunakan model pembelajaran Number Head Together (NHT). Setelah peneliti mengadakan tes awal rencana selanjutnya adalah menerapkan pembelajaran dengan menggunakan model Number Head Together (NHT) sesuai dengan tujuan kedatangan peneliti di SDN 18 Baruga untuk melaksanakan PTK (Penelitian Tindakan Kelas).

\section{Siklus I}

Pertemuan 1 Siklus I, dilaksanakan pada hari Selasa, 22 November 2018. Kegiatan pembelajaran pada siklus I pertemuan pertama ini berlangsung selama 2x35 menit di mulai pada pukul 07.30 - 09.40 dengan materi "Menentukan FPB dari Dua Bilangan" Sedangkan Pertemuan ke 2 Siklus I, dilaksanakan pada hari Selasa, 26 November 2018. Pertemuan kedua berlangsung selama $2 \times 35$ menit dimulai dari pukul 07.30 - 09.40. dengan materi “Menentukan KPK dari Dua Bilangan". Kegiatan pembelajaran menggunakan model Numbered Head Together (NHT) dilaksanakan sesuai skenario pembelajaran yang telah disiapkan.

Berdasarkan hasil tes tindakan siklus I diperoleh nilai tertinggi adalah 80 dan nilai terendah 50 dengan rata-rata 63,46 dimana 12 siswa masuk kategori tuntas atau sekitar 46\% mencapai ketuntasan hasil belajar dan 14 siswa lainnya masuk kategori tidak tuntas atau sekitar 54\% tidak mancapai ketuntasan belajar. Dimana dalam kategori tuntas dengan nilai $\geq 70$ dan kategori belum tuntas dengan nilai $<70$ sehingga indikator kinerja yang ditetapkan belum tercapai yaitu $80 \%$ siswa mendapat nilai $\geq 70$ sehingga penelitian ini berlanjut pada siklus II. Faktor yang menyebabkan sehingga belum tercapai indikator yang telah ditetapkan adalah siswa belum sepenuhnya aktif dalam proses pembelajaran dan masih kurangnya siswa yang memperhatikan penjelasan guru dalam menyampaikan materi dan beberapa siswa masih belum terbiasa dengan model yang diterapkan, perhatian siswa hanya diawal pembelajaran saja, Siswa juga masih belum berani dan belum bisa untuk bertanya dan menjawab pertanyaan bahkan siswa masih kurang percaya diri saat maju persentasi di depan kelas. Seperti yang disampaikan oleh Putu Dewi Ariestuti, I Wayan dan Rini Kristiantari, bahwa siswa masih kesulitan dalam melaksanakan proses pembelajaran (diskusi) secara berkelompok karena kecerdasan mereka berbeda-beda, kebanyakan dari siswa kurang aktif membuat pertanyaan dan hanya mendengarkan ceramah dari guru. Beberapa siswa terlihat tidak bersemangat dan perhatian mereka kurang fokus dalam proses pembelajaran. Siswa juga masih kurang berani dalam membacakan hasil temuan yang telah dibuatnya ke depan kelas karena kurang percaya diri. (Putu Dewi Ariestuti, dkk, 2014). Bila melihat rata-rata hasil belajar siswa berdasarkan pelaksanaan penelitian mulai dari tes awal sampai setelah dilaksanakannya tindakan siklus I menunjukkan hasil belajar siswa mengalami peningkatan, terbukti dari rata-rata hasil belajar yang diperoleh siswa dimana pada tes awal siswa 
hanya memperoleh rata-rata hasil belajar sebesar 51, kemudian setelah pelaksanaan siklus I meningkat menjadi 63,46 dengan persentase peningkatan mencapai $25 \%$.

Pada proses pembelajaran sebagian besar peserta didik mempunyai semangat yang tinggi untuk mengikuti kegiatan-kegiatan yang ada selama proses pembelajaran berlangsung. Mereka juga terlihat antusias dalam belajar, menanggapi positif dorongan-dorongan yang diberikan guru, dan mempunyai semangat untuk mencapai kompetensi-kompetensi yang telah diberikan oleh guru. Hal ini seperti yang dikatakan oleh Yulia Maftuhah Hidayati, bahwa peserta didik akan selalu aktif mengungkapkan dan mengembangkan ide atau gagasan mereka jika peserta didik merasa belum paham dengan materi yang disampaikan guru, mereka tidak segan bertanya pada guru dan meminta guru mengulangi materi tersebut. (Yulia Maftuhah, 2012).

\section{Siklus II}

Pada tahap pelaksanaan siklus II sama dengan tahap pelaksanaan siklus I yang dimana terdiri dari $2 \mathrm{x}$ pertemuan dengan waktu 2 x 35 menit. Pertemuan ke 1 Siklus II, dilaksanakan pada hari Selasa, 27 November 2018. Kegiatan pembelajaran pada pertemuan 1 siklus II berlangsung selama 2 x 35 menit dimulai pada pukul 07.30 - 09.40 dengan materi "Hal-hal yang berkaitan dengan FPB". Sedangkan Pertemuan ke 2 Siklus II, dilaksanakan pada hari Kamis, 29 November 2018. Kegiatan pembelajaran pada pertemuan 2 siklus II ini berlangsung selama 2 × 35 menit dimulai pada pukul $07.30-09.40$ dengan materi "Hal-hal yang berkaitan denga KPK". Setelah pelaksanaan tindakan siklus 2 selama dua kali pertemuan, diadakan evaluasi menggunakan tes dengan tujuan untuk mengetahui sejauh mana perkembangan dan peningkatan hasil belajar siswa dengan menggunakan model pembelajaran Number Head Together (NHT). Hasil belajar siswa dikatakan tuntas apabila siswa secara individu mendapat nilai $\geq 70$, hal ini sesuai dengan KKM Mata Pelajaran Matematika SDN 18 Baruga Kecamatan Baruga Kota Kendari. Setelah pelaksanaan tindakan siklus II diketahui perolehan nilai tertinggi siswa adalah 100 dan nilai terendah adalah 60 dengan nilai rata-rata 85,38 sementara ketuntasan hasil belajar adalah $88,46 \%$ yang berarti jumlah siswa tuntas yang memperoleh nilai 70 keatas berjumlah 23 siswa dan 3 siswa belum tuntas atau sekitar $11,53 \%$ yang tidak mencapai nilai 70 .

Pada tahap siklus 2 ini seluruh siswa sudah terlihat terbiasa dengan penerapan pembelajaran yang diterapkan oleh peneliti sehingga proses pembelajaran berjalan dengan lancar, teliti, situasi kelas tampak hidup, siswa bisa menikmati tahap demi tahap pembelajaran berjalan dengan lebih percaya diri dan lancar. Sama seperti yang dikatakan oleh Husni Sabil, bahwa tingginya aktifitas pembelajaran yang dilakukan peserta didik disebabkan oleh kualitas perencanaan dan pelaksanaan pembelajaran yang dilakukan oleh guru, apalagi perencanaan dan pelaksanaan tersebut disusun berdasarkan proses pembelajaran yang sudah dilakukan sebelumnya. (Husni Sabil, 2011). Berdasarkan hasil tersebut menunjukkan bahwa belajar dengan mengggunakan model pembelajaran Number Head Together (NHT) selain dapat meningkatkan aktivitas siswa juga dapat meningkatkan hasil belajar siswa. Hal ini sama seperti yang dijelaskan Alie pada penelitiannya yang menyatakan bahwa model pembelajaran kooperatif tipe Number Head Together (NHT) dapat meningkatkan hasil belajar siswa karena siswa melakukan diskusi dengan sungguh-sungguh dan juga siswa yang pandai dapat mengajari siswa yang kurang pandai serta setiap siswa menjadi siap semua dalam mengikuti pembelajaran. (Alie, $\mathrm{N}, \mathrm{H}$, 2013)

Hasil belajar siswa tersebut menunjukkan bahwa pelaksanaan pembelajaran pada siklus II secara umum dapat mengantarkan siswa mencapai ketuntasan belajar yang di harapkan dan telah mencapai indikator ketuntasan belajar yang ditargetkan yaitu $80 \%$ secara klasikal, demikian pula jika melihat dari nilai rata-rata hasil belajar siswa meningkat dari siklus I sebesar 63,46 dan setelah pelaksanaan tindakan pada siklus II menjadi 85,38, dengan memperhatikan analisis hasil belajar siswa tersebut menunjukkan adanya peningkatan hasil belajar siswa dari silklus I sampai setelah pelaksanaan tindakan siklus II dengan persentase peningkatan sebesar 34,54\%. Dengan adanya peningkatan hasil belajar siswa yang selalu meningkat pada setiap pelaksanaan tindakan dalam satu siklus membuktikan bahwa penerapan pembelajaran dengan menggunakan model Number Head Together (NHT) dapat meningkatkan hasil belajar siswa pada pelajaran Matematika di kelas IVa SDN 18 Baruga Kecamatan Baruga Kota Kendari. Hasil dan pencapaian ini menandakan semakin sempurnanya pelaksanaan 
skenario pembelajaran yang dilaksanakan dan adanya peningkatan aktifitas siswa dan hasil belajar yang meningkat dalam penggunaan model pembelajaran Number Head Together (NHT). Hal ini merujuk pada hasil tes siklus II di atas, maka penelitian ini dihentikan pada tahap siklus II karena indikator keberhasilan yang telah ditetapkan telah tercapai, dengan demikian upaya peningkatan hasil belajar siswa melalui penerapan model pembelajaran Number Head Together (NHT) telah tercapai dengan baik. Hasil ini di perkuat oleh Sugiawan yang menjelaskan bahwa penerapan pembelajaran kooperatif tipe Number Head Together (NHT) mampu meningkatkan hasil belajar matematika siswa, (Sugiawan, 2014).

\section{PEMBAHASAN}

Pembelajaran Number Head Together (NHT) mengajak siswa untuk aktif di kelas. Pembelajaran lebih berpusat pada siswa dibandingkan guru. Guru hanya berperan sebagai pembimbing dan motivator. Dalam pembelajaran Number Head Together (NHT) siswa dituntut mampu bekerja sama dalam kelompok, berani, menganalisis dan memecahkan permasalahan yang diberikan baik secara individu maupun kelompok. Selain itu, siswa dilatih bekerja sama dan bertanggung jawab dalam kelompoknya. Pembelajaran Number Head Together (NHT) memberikan kesempatan kepada siswa untuk belajar secara kelompok dan membuat siswa menjadi lebih peduli atau merasa bertanggung jawab terhadap anggota kelompoknya sehingga pembelajaran menjadi bermakna bagi siswa. Keberanian untuk menyampaikan pendapat juga dikembangkan dan keterampilan siswa untuk berkomunikasi melalui diskusi seperti bertanya, menjawab, mengemukakan pendapat di latih dan dikembangkan melalui kerja kelompok. Siswa yang lebih cerdas dan berani tampil akan membuat siswa lain termotivasi untuk berani tampil dan berbagi ide serta pendapat sehingga pengetahuan menjadi lebih berkembang. Kesuksesan lebih mudah dicapai oleh para anggota kelompok yang bekerja sama dari pada kesuksesan yang diraih seseorang yang berusaha sendiri. (Kula Ginting, 2013)

Lebih lanjut menurut Anita Lie menambahkan bahwa Numbered Head Together (NHT) adalah tehnik pembelajaran kooperatif dimana tekhnik ini memberikan kesempatan kepada siswa untuk saling membagikan ide-ide dan mempertimbangkan jawaban yang paling tepat, selain itu teknik ini juga mendorong siswa untuk melaksanakan tanggung jawab pribadinya dalam saling keterkaitan dengan rekan-rekan kelompoknya. Teknik ini bisa digunakan dalam semua mata pelajaran dan untuk semua tingkat usia anak didik (Anita Lie, 2010). Model pembelajaran Numbered Heads Together (NHT) merupakan salah satu tipe model dalam pembelajaran kooperatif. Pembelajaran kooperatif didefinisikan sebagai sekelompok kecil pembelajar yang bekerja sama menyelesaikan masalah, merampungkan tugas, atau menyelesaikan suatu tujuan bersama. Bahwa model pembelajaran kooperatif merupakan teknik-teknik kelas praktik yang dapat digunakan guru setiap hari untuk membantu siswa belajar setiap mata pelajaran, mulai dari keterampilan-keterampilan dasar sampai pemecahan masalah yang kompleks (Titin Hartanti, Desi Tri Widiyanti, Dkk, 2012). Berdasarkan beberapa teori diatas maka dapat disimpulkan bahwa pembelajaran kooperatif tipe Number Head Together (NHT) adalah salah satu varian atau model dari pembelajaran kooperatif dimana guru membagi siswa dalam kelompok kecil yang berisi 4-5 orang secara heterogen dimana setiap siswa dalam masing-masing kelompok mendapat nomer diri atau nomer kepala yang berbeda, dimana saat proses pembelajaran siswa memikirkan bersama jawaban dari apa yang ditanyakan guru bersama kelompoknya, untuk selanjutnya menjawab pertayaan tanpa tahu nomer berapa yang akan di panggil oleh guru. Hal ini menunjukkan bahwa hasil belajar siswa dalam proses pembelajaran dengan menerapkan model Number Head Together (NHT) menunjukkan adanya peningkatan.

Berdasarkan hasil observasi dan refleksi maka dapat disimpulkan bahwa pembelajaran Matematika dengan menggunakan model Number Head Together (NHT) dapat meningkatkan hasil belajar siswa pada mata pelajaran Matematika di kelas IVa SDN 18 Baruga. Hal ini dikarenakan Number Head Together (NHT) merupakan model pembelajaran yang sifatnya dapat memberikan tanggung jawab dan melibatkan siswa dalam belajar kelompok maupun individu sehingga siswa fokus dan aktif dalam mengikuti dan mempelajari materi yang diajarkan oleh guru, sehingga mereka akan paham dan mengerti dengan materi yang dipelajari dan berimplikasi pada meningkatnya hasil belajar, siswa akan lebih aktif dan bertanggung jawab dalam proses pembelajaran. Hal ini sesuai tuntutan sebagaimana yang disampaikan oleh Purwanto bahwa hasil belajar ialah hasil yang menunjuk pada 
suatu perolehan akibat dilakukannya suatu aktivitas atau proses yang mengakibatkan berubahnya input secara fungsional. Belajar dilakukan untuk mengusahakan adanya perubahan perilaku pada individu yang belajar. Perubahan perilaku itu merupakan perolehan yang menjadi hasil belajar. (Purwanto, 2011). Hal tersebut sejalan dengan pendapat Purwanti yang menyatakan bahwa model pembelajaran kooperatif tipe Number Head Together NHT adalah suatu model pembelajaran yang lebih mengedepankan kepada aktifitas siswa dalam mencari, mengolah, dan melaporkan informasi dari berbagai sumber yang akhirnya dipresentasikan di depan kelas sehingga hasil belajar siswa dapat meningkat, (Purwanti, 2016)

\section{KESIMPULAN}

Penerapan model pembelajaran Number Head Together (NHT) sangat cocok diterapkan pada siswa kelas IVa SDN 18 Baruga Kecamatan Baruga Kota Kendari. Hal tersebut dapat meningkatkan hasil belajar siswa dengan materi Faktor Persekutuan Terbesar (FPB) dan Kelipatan Persekutuan Terkecil (KPK) dimana nilai rata-rata siswa setelah tindakan siklus I meningkat dibandingkan dengan nilai tes awal, yakni dari 51 menjadi 63 dengan persentase kenaikan sebesar $25 \%$ begitu juga dengan Nilai rata-rata siswa setelah tindakan siklus II meningkat dibandingkan dengan nilai rata-rata siklus 1 , dari 63 menjadi 85 dengan persentasi peningkatan sebesar 34,54\%. Kenaikan presentasi pada siklus II ini telah memenuhi indikator kinerja yang telah ditetapkan yaitu $80 \%$ siswa telah mendapat nilai minimal 70. Terjadi perubahan sikap siswa selama proses pembelajaran sesuai dengan hasil observasi yaitu dengan adanya penerapan model pembelajaran Number Head Together (NHT) dapat meningkatkan rasa percaya diri siswa untuk bertanya baik kepada guru maupun kepada temannya tentang materi yang tidak dimengerti serta dapat meningkatkan kerjasama siswa dalam diskusi kelompok. Sehingga penerapan model pembelajaran Number Head Together (NHT) dapat meningkatkan hasil belajar siswa sekaligus juga meningkatkan aktifitas mengajar guru dan siswa dalam proses pembelajaran.

\section{DAFTAR PUSTAKA}

Alie, N. H, 2013, Penggunaan Model Pembelajaran Kooperatif Tipe NHT untuk Meningkatkan Hasil Belajar Siswa Kelas X 2 SMA Negeri 3 Gorontalo pada Materi Jarak pada Bangun Ruang. Jurnal Entropi [Online]. Vol 08 (01),

Anita Lie, 2010, Cooperative Learning: Mempraktikan Cooperative Learning di Ruang-ruang Kelas, (Jakarta: PT. Grasindo),

Aniza, Muh. Hasbi dan Baharuddin, 2017, Penerapan Model Pembelajaran Kooperatif Tipe Numbered Heads Together (NHT) Untuk Meningkatkan Hasil Belajar Siswa Pada Materi Perbandingan Di Kelas VII Tulip SMP Negeri 14 Palu, Jurnal Elektronik Pendidikan Matematika Tadulako, Volume 04 Nomor 03.

Ginting Kula, 2013 Penerapan Model Pembelajaran Contextual Teaching And Learning Untuk Meningkatkan Aktivitas Dan Hasil Belajar IPS Siswa Kelas V SD Negeri 060885 Medan, JURNAL TEMATIK, ISSN : 1979-0633, Volume : 003/No.12/DIKSAS,

Hariyanti, Sri dan Naim Musyafik, 2013, Pengaruh Penerapan Metode CTL (Contextual Teaching an Learning) terhadap Peningkatan Mutu Pendidikan pada The Naff Elementary School, Jurnal Ilmu Manajemen, REVITALISASI, Vol. 2, Nomor 2,

Hartanti, Titin 2013 "Penggunaan Model Number Head Together dalam Pembelajaran Matematika di Sekolah Dasar”. Kalam Cendekia PGSD Kebumen,

Hidayati, Yulia Maftuhah, 2012, Pembelajaran Penjumlahan Bilangan Pecahan Dengan Metode Contextual Teaching And Learning (CTL) di SD Muhammadiyah Program Khusus, Kota Barat, Surakarta. Jurnal Penelitian Humaniora, Vol. 13, No. 1.

Irhas, 2014, Pengaruh Pengawasan Kepala Sekolah Terhadap Peningkatan Kinerja Guru Di Sekolah Menegah Atas (SMA) Negeri 6 Kendari, Skripsi (Kendari: Program Strata 1 STAIN Sultan Qaimuddin,

La Anse, Muhammad Ilham. 2018. The Implementation of Cooperative Learning (Numbered Head Together) to Boost Students' Learning Outcome in Social Studies Subject. IOP Conference Series: Earth and Environmental Science. IOP Publishing. 
Mutia Agisni Mulyan,dkk, 2016, Penerapan Model Kooperatif Tipe Numbered Heads Together (NHT) Untuk Meningkatkan Hasil Belajar Siswa Pada Materi Kenampakan Alam Dan Sosial Budaya, Jurnal Pena Ilmiah PGSD Kelas UPI Kampus Sumedang, Vol. 1, No. 1

Purwanti, S. A. 2016. Penerapan Model Pembelajaran Kooperatif Tipe Numbered Heads Together untuk Meningkatkan Hasil Belajar Mata Pelajaran Matematika [Online]. Tersedia: http://ejournal.unpak.ac.id/download.php?file=mahasiswa\&id=721\&name=SELVIANI\%20 AYO\%20JURNAL.pdf

Purwanto, 2011, Evaluasi Hasil Belajar, Yogyakarta: Pustaka Pelajar.

Putu Dewi Ariestuti, I Wayan Darsana, Rini Kristiantari, 2014 Penerapan Pendekatan Contextual Teaching And Learning (CTL) Untuk Meningkatkan Keaktifan Dan Hasil Belajar IPA Siswa Kelas VI SD 3 TONJA, Jurnal Mimbar PGSD Universitas Pendidikan Ganesha, Vol:2, No:1,

Rika Firma Yenni, 2016 Penggunaan Metode Numbered Head Together (NHT) Dalam Pembelajaran Matematika, Jurnal Pendidikan Matematika Universitas Tamansiswa Palembang, JPPM Vol. 9 No.2,

Sabil Husni, 2011 Penerapan Pembelajaran Contextual Teaching And Learning (CTL) Pada Materi Ruang Dimensi Tiga Menggunakan Model Pembelajaran Berdasarkan Masalah (MPBM) Mahasiswa Program Studi Pendidikan Matematika FKIP INJA, Jurnal Edumatica, ISSN 2088-2157, Volume 1 Nomor 1,

Sugiawan, R. 2014 Meningkatkan Aktivitas Dan Hasil Belajar Matematika Melalui Pembelajaran Kooperatif Tipe NHT. Portal E-Journal Universitas Lampung [Online]. Vol 03..(01),

Titin Hartanti, Desi Tri Widiyanti, Dkk, 2012, Penggunaan Model Numbered Heads Together (Nht) Dalam Pembelajaran Matematika Di Sekolah Dasar, Jurnal PGSD FKIP Universitas Sebelas Maret), 